\title{
Atherogenesis, Inflammation and Autoimmunity - An Overview
}

\author{
Katja Lakota et al.* \\ University Medical Centre-Ljubljana, Rheumatology, Ljubljana, \\ University of Primorska, FAMNIT, Koper, \\ Slovenia
}

\section{Introduction}

In the $16^{\text {th }}$ century, Leonardo Da Vinci had described "the narrowing of the passage of blood vessels, thickening of the coats of these vessels and hardening of arteries" in his work (Boon, 2009). This is the first known documentation of atherosclerosis (AS). Today, our understanding of atherogenesis as a process of a chronic inflammatory disease has been greatly promoted by many theories, such as, the cellular cycle of cholesterol and hypercholesterolemia, dysfunction of endothelial cells, oxidized lipoproteins, discovery of scavenger receptors and response to injury theory, among others. The factors leading to the elucidation of atherogenesis are still not all known, since AS can persist silently (subclinically) without showing any serious symptoms for a longer period. That, together with the fact that AS is not limited to warm-blooded vertebrates and the occurrence of intimal thickening of coronary arteries in rabbitfish (Duran et al., 2010), as well as evidence of coronary AS in salmonids (Farrell, 2002), brings proof that AS is still a largely elusive, complicated and multi-component disease.

AS is not a modern world disease as determined by recent images obtained from coronary arteries and the aorta of ancient mummies. Atheromatous lesions, as well as aortic AS were identified in an Aleutian mummy from Alaska originating from 400 AD (Zimmerman, 1998). In 2009, images generated by computer tomography of vascular calcifications in examined Egyptian mummies found that 16 out of the 22 examined mummies had identifiable cardiovascular tissue, with definite AS present in 5 and AS found in additional 4 mummies (together 56\% of total) (Allam et al., 2009). This study was recently expanded to 52 ancient Egyptian mummies from the Middle Kingdom to the Greco-Roman period and identified cardiovascular structures in 44 mummies, with 20 of these showing either definite AS ( $n=12$, as defined by calcification within the wall of an identifiable artery) or probable AS $(n=8$, as defined by calcifications along the expected course of an artery) (Allam et al., 2011).

\footnotetext{
*Andrej Artenjak¹, Sasa Cucnik ${ }^{1}$, Jana Brguljan-Hitij², Borut Cegovnik²,

Barbara Salobir ${ }^{2}$, Rok Accetto ${ }^{2}$, Borut Bozic ${ }^{1,3}$, Blaz Rozman ${ }^{1}$ and Snezna Sodin-Semrl ${ }^{1,4}$

1 University Medical Centre-Ljubljana, Rheumatology, Ljubljana, Slovenia

${ }^{2}$ University Medical Centre-Ljubljana, Hypertension, Ljubljana, Slovenia

${ }^{3}$ University of Ljubljana, Faculty of Pharmacy, Clinical Biochemistry, Ljubljana, Slovenia

${ }^{4}$ University of Primorska, FAMNIT, Koper, Slovenia
} 
The calcifications were located in the aorta, as well as coronary, carotid, iliac, femoral and peripheral arteries. The 20 mummies with definite and probable AS were significantly older at time of death (mean age $45.1 \pm 9.2$ years) as compared to mummies that had cardiovascular tissue identified without AS (mean age $34.5 \pm 11.8$ years). Since social status (mummies were usually of higher status, than others in the population), diet (mainly wildlife and grains) and tobacco (not yet known) were not risk factors in the life of ancient Egyptians, they could not contribute to the development of AS in this population. Age, however has been re-affirmed with these studies, as one of the most important independent systemic risk factors for AS.

\section{Brief clinical characterization of the disease}

AS is a chronic, multifocal immunoinflammatory, fibroproliferative disease and is the most common form of arteriosclerosis. AS is a disease of the arterial wall, which often starts in young people. In middle-aged individuals, AS can start to appear in clinically recognizable forms, such as coronary artery disease (CAD), cerebral vascular or peripheral artery disease. It can affect all large and medium-sized arteries including the coronary, carotid, cerebral arteries, the aorta, its branches and main arteries of the extremities. Areas of non-laminar blood flow are highly susceptible to plaque formation.

The clinical endpoints of AS may result as a consequence of several mechanisms, such as:

1. artery-to-artery embolism of thrombus formed on an atherosclerotic plaque,

2. atheroembolism of cholesterol crystals or other atheromatous debris,

3. acute thrombotic occlusion resulting from plaque rupture,

4. structural disintegration of the arterial wall resulting from dissection or subintimal hematoma, and

5. reduced perfusion resulting from critical stenosis or occlusion caused by progressive plaque growth

Ultrasound is one of the most commonly used noninvasive examinations for assessment of early and advanced atherosclerotic vascular changes, also of the carotid intima media thickness. However, ultrasound has limited diagnostic and prognostic value, and for preoperative procedures, arteriographies and other methods of the involved vessels are necessary.

AS is considered to be the leading cause of death and loss of disability adjusted life-years worldwide, particularly in the developed countries, according to United States Statistical Update from 2011 (Roger et al., 2011). CAD accounted for $\cong 1$ of every 6 deaths and stroke 1 of 18 deaths in 2007 . Recently, peripheral artery disease was reported to be present in $12 \%$ of United States citizens (Beers et al., 2006).

\section{Inflammation and the involvement of cells/molecules in atherosclerosis}

Inflammation contributes to the formation and progression of AS (Libby, 2002; Moubayed et al., 2007). Since AS represents a chronic inflammatory state, levels of C-reactive protein (CRP) are important, and were found to be an independent predictor of cardiovascular disease (CVD) (Fruchart et al., 2004), although other studies have not been able to confirm this (Kullo \& Ballantyne, 2005). Serum amyloid A (SAA) has been reported to also play a role in atherosclerosis (King et al., 2011) which has been supported by animal models (Chait et al., 2005; Hua et al., 2009; Malle \& De Beer, 1996). In human primary coronary artery 
endothelial cells, SAA was reported to induce the release of interleukin-6 (IL-6), IL-8 and stimulate the expression and release of soluble intercellular adhesion molecule (sICAM) and soluble vascular adhesion molecule (sVCAM), as well as E-selectin synthesis. The data indicated greater susceptibility of coronary artery endothelial cells (in comparison to human umbilical vein endothelial cells) to SAA (Lakota et al., 2007) which indicated the potential role of SAA in CAD. Studies for fibrinogen consistently link this factor, which is involved in both inflammation and thrombosis, with AS burden and risk of coronary heart disease (CHD) (Kullo \& Ballantyne, 2005). Lipoprotein-associated phospholipase A2 (Lp-PLA2) is a novel biomarker of vascular-specific inflammation providing information about atherosclerotic plaque inflammation and stability. Elevated levels of serum Lp-PLA2 are indicative of rupture-prone plaques and a strong independent predictor of cardiovascular risk (Colley et al., 2011). Most recently, Herder et al. reported on biomarkers associated with prediction of incident coronary events (Herder, Karakas, et al., 2011). The group mentioned the following markers: IL-6, IL-8, IL-18, macrophage migration inhibitory factor (MIF), monocyte chemotactic protein-1, interferon- $\gamma$ inducible protein-10, transforming growth factor- $\beta 1$ (TGF- $\beta 1$ ), sE-selectin and sICAM (Herder, Baumert, et al., 2011). The data showed that the combination of blood biomarkers could improve the prediction of cardiovascular outcome above the traditional ones used.

Some infectious diseases represent an independent initiator of vascular inflammation which can contribute to atherogenesis and progression of AS. Bacteria and viruses can upregulate cytokines, chemokines and acute phase reactants, such as CRP and SAA, which lead to endothelial dysfunction. Overall, expression of Toll-like receptors in the atheroma, mouse model experiments and the role of genetic polymorphisms, all currently suggest microbe activation of inflammation in plaques and AS progression (Vallejo, 2011). Infection is also known to convert a lipidogenic profile into a pro-atherogenic one (Khovidhunkit et al., 2000).

Infections important in association with AS were shown in many studies and include the following infectious agents Herpes virus, C. pneumonie, P. gingivitis, H. pylori, among others (Kowalski et al., 2006; Ludewig et al., 2004; Ross, 1999). There was also presence of bacterial antigens reported in atheroma (Ott et al., 2006). The latter finding raises the question of single antigen importance versus total infectious burden in accelerating AS (Gabrielli et al., 2002). Presence of antibodies against infectious agents represent a risk factor for CVD. In terms of specific antigen involvement in AS, the following (among others) have been reported: H.pylori heat shock protein (HSP)-60 elicited antibodies can crossreact with endogenous molecules, stress-related endothelial HSP-60 and the presence of HSP-60-specific T lymphocytes in the circulation, may increase the risk of AS (Ayada et al., 2007). Occurrence of antiphospholipid antibodies after certain infections is also common and can lead to initial endothelial dysfunction (Altman, 2003). Latency and intracellular infection importance stays an open ended question (especially in C.pneumonie, Cytomegalovirus). Long term effects of infections on AS progression are unclear, however statistics show undoubtedly more cases of stroke and myocardial infarction in the first 3 days following an acute urinary/respiratory infection with declining numbers in following weeks (Graham et al., 2007).

A unifying view of the pathophysiology of AS proposes that inflammation has a key role by transducing the effects of many known risk factors of the disease. Although the combined experimental and clinical evidence may convince some, the chicken and egg problem about causality, remains unsolved (Libby et al., 2011). 


\subsection{Initial injury}

Endothelial cells provide a physical barrier layer between the circulatory system and the intima, however the cells also actively synthesize molecules responsible for the maintenance of circulatory homeostasis and participate in plaque development.

The initial process in the development of AS is isolated endothelium injury and subsequent endothelial activation followed by expression of different pro-inflammatory cytokines, chemokines and adhesive molecules resulting in monocyte attraction, the rolling mechanism and their migration into the tunica intima (Jan et al., 2010; Ross, 1999). Monocytes transform into macrophages, the activation of which leads to the hallmark of plaque development or foam cell formation. An important molecule in this process is oxidized low density lipoproteins (oxLDL), which originates from retained LDLs in the tunica intima. Molecules of oxLDL and their binding to scavanger receptors on macrophages stimulates the accumulation of lipids in the cells and the formation of foam cells (Hansson, 2005).

When inflammatory cells (such as leukocytes, monocytes and macrophages) migrating into the intima, start to accumulate subendothelial lipid, particularly oxidized lipid, this exacerbates the initial, local inflammatory reaction and maintains activation of the overlying endothelium. This results in continued expression of adhesion molecules and pro-inflammatory cytokines and chemokines perpetuating cell activation. Normally, the endothelium shows anti-adhesive, anti-thrombotic and vasoregulatory properties. Thus, stress conditions, mechanical damage or patho-physiological stimulation can cause modified endothelial cell characteristics (Stoltz et al., 2007). Endothelial injury can be different based on the different original vascular beds the cells arise from. Their physiological roles in coagulation, hemodynamics and susceptibility to patho-physiological stimuli can also differ depending on the vascular bed origin and the influence of the microenviroment (Aird, 2007; Cines et al., 1998; Lacorre et al., 2004; Luu et al., 2010; Yano et al., 2007). For example, differences in endothelial cell responses were described for activation with tumour necrosis factor $\alpha$ (TNF- $\alpha$ ) (Lehle et al., 2007; Methe et al., 2007; Viemann et al., 2006), SAA and IL-1 $\beta$ (Lakota et al., 2007; Lakota et al., 2009) and oxLDL (Deng et al., 2006). Recently, endothelial damage has been reported as being able to be repaired with endothelial progenitor cells (Bai et al., 2010).

Endothelial cells seem to be involved prevalently in the earlier stages of atherogenesis, leading to initial vascular injury, as well as in later stages, when they detach in response to injury and enter the circulation. Circulating endothelial cells can be used as a marker of vascular injury. Their number increase is associated with CVD, as well as they can serve as an accurate predictor of major adverse events following myocardial infarction. They also inversely correlate with flow-mediated dilatation and positively correlate with markers of endothelial injury (such as von Willebrand factor, tissue plasminogen activator inhibitor, Eselectin) and prothombotic state (tissue factor). They are rarely found in healthy individuals, but are increased and correlate with disease activity in different vasculitides, in systemic lupus erythematosus (SLE) and systemic sclerosis (SSc) (Boos et al., 2006). Interestingly, Mutin et al. showed increased circulating endothelial cells in acute myocardial infarction and unstable angina without increased levels of markers of activation (ICAM, VCAM, Eselectin) and no apoptosis (Mutin et al., 1999).

\subsection{Progression of atherosclerotic plaques}

Early atherosclerotic lesions called fatty streaks involve a growing extracellular lipid core within the atherosclerotic plaques. The next stage of atherosclerotic plaque formation 
involves the proliferation and migration of smooth muscle cells into the tunica intima, accumulation of collagen and fibrous cap formation (Hansson, 2005; Libby, 2002). T lymphocytes with a prevailing Th1 response, together with smooth muscle cell proliferation and deposition of collagenous fibers contribute to the fibrous cap formation. Fibrosis and collagen accumulation have a patho-physiological parallel in other chronic inflammatory diseases such as rheumatoid arthritis (RA), cirrhosis and pulmonary fibrosis, among others, where monocytes and lymphocytes are also the active players. In later stages of AS plaque development, expression of proteases increases (i.e. matrix metalloproteinases (MMPs)) leading to degradation of collagen.

During the development of AS plaques, monocyte-derived macrophages and Tlymphocytes that invade evolving atherosclerotic lesions produce soluble inflammatory mediators (cytokines and chemokines) which are very important in the perpetuation of the disease. Certain cytokines and chemokines (i.e. IL-1, IL-12, IL-18, TNF- $\alpha$, MIF, interferon- $\gamma$ (IFN- $\gamma)$, and granulocyte macrophage colony stimulating factor (GM-CSF) have explicit pro-atherogenic characteristics, others (i.e. IL-10 and probably IL-5) have anti-atherogenic properties, while IL-4, IL-6, and GM-CSF can have both pro- or antiatherogenic properties. Several of the pro-atherogenic cytokines affect plasma cholesterol levels, indicating that inflammation and lipid metabolism are interlinked processes in AS (Kleemann et al., 2008).

Fatty streaks do not necessarily progress into advanced lesions. Certainly the progression of plaques is not linear (Figure 1) and depends largely on the microenvironment. Plaques can be clinically silent for years. Almost all adolescent children may already show some evidence of fatty streaks (Kumar et al., 2007).

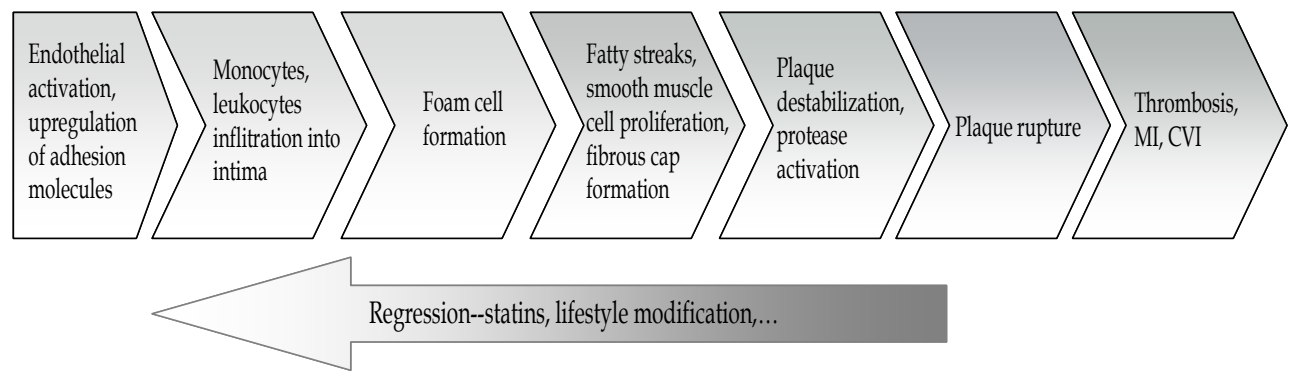

Fig. 1. Simplified putative scheme of progression/regression of atherosclerosis at the cellular and molecular levels. MI, myocardial infarction; CVI, cerebrovascular insult

Clinical prognosis is determined by the biological nature of the atherosclerotic plaque. Atheroma with active inflammatory processes are most prone to ruptures (Libby, 2002; Ross, 1999) and inflammation largely accounts for progression of stable to unstable angina (J.T. Wu \& L.L. Wu, 2005). Rupture prone/unstable plaques are the ones with a large lipid core, many inflammatory cells and a thin fibrous cap (Gziut \& Gil, 2008; Krone \& MullerWieland, 1999).

There are three typical types of cellular/molecular influences of plaque rupture, among others:

a. desquamation of the endothelium (due to proinflammatory mediators, MMPs, T cells which attack the basal membrane of the endothelium) which uncovers the collagen and thrombosis can occur. Although desquamation is common and often asymptomatic it 
accounts for $1 / 4$ of fatal coronary thromboses (Libby, 2002). Mast cells contribute to endothelial erosions by releasing proteases that degrade cadherin and fibronectin (Mayranpaa et al., 2006)

b. disruption of neo-angiogenic blood vessels, growing in the atheroma full of growth factors. This leads to thrombin activation, collagen expression and smooth muscle cell proliferation (Libby, 2002)

c. fibrous cap rupture is the most common of plaque rupture and is due to inflammation in the lipid core, MMPs and tissue factor release from plaques. TGF- $\beta$ and vascular endothelial growth factor released for the purpose of wound healing of the ruptures causes additional fibroses which narrow further the lumen of the vessel and can cause ischemia.

Major clinical complications and subclinical events are presented in Figure 2.

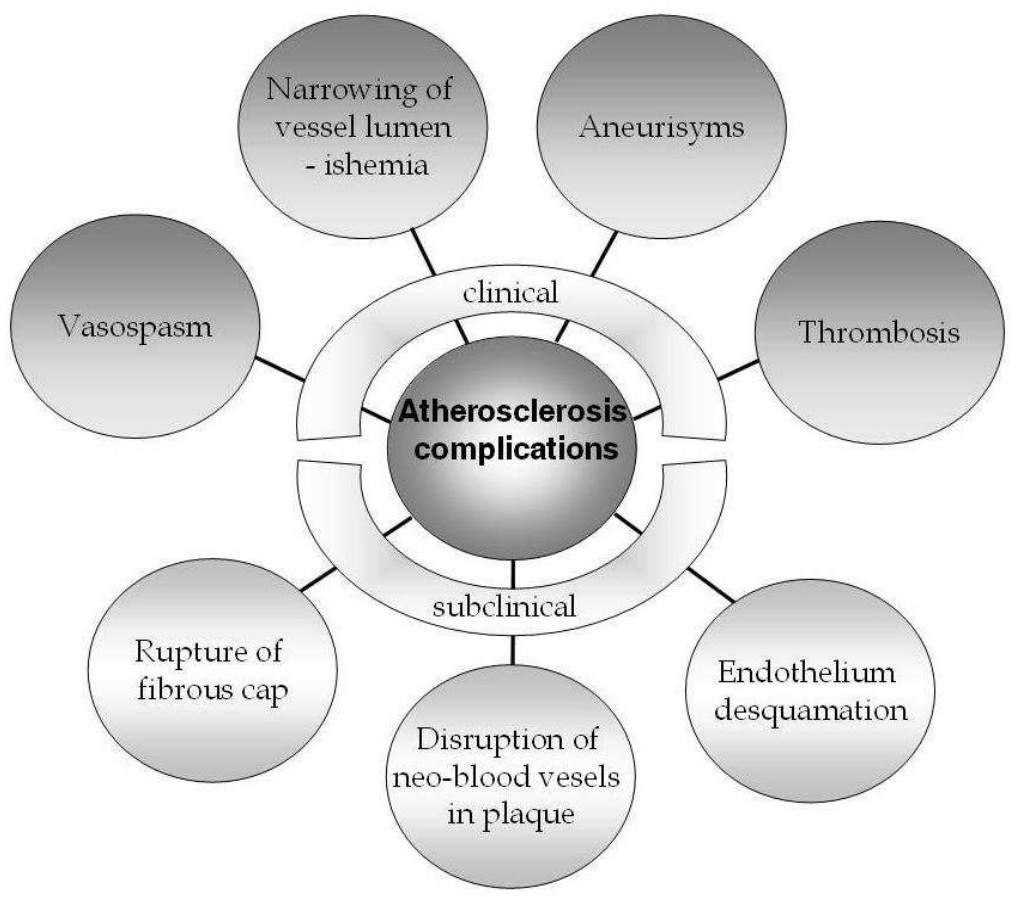

Fig. 2. Some clinical and subclinical atherosclerosis complications

\subsection{Regression of atherosclerotic plaques}

Previously, AS was thought to be reversible in early stages with changes of lifestyle and dietary modifications, as shown on animal models (J.J. Badimon et al., 1990; Malinow, 1983) and was believed to be reversible only to the stages before fatty streak formation. Currently, however, it is accepted that later stages can also be reversible as well. Some important regressions of even necrotic lesions and foam cell disappearance were achieved with injections of cholesterol-free phosphocholine liposomes which lower total cholesterol and mobilize cholesterol from plaques in animals (Williams et al., 2008). In regression of AS, 
endothelium-dependent relaxation improves, as well as hypersensitivity of blood vessels, however maximal vasodilator activity/capacity does not improve (presumably due to fibrosis of arteries) (Heistad et al., 1990).

There are some problems occurring with evaluating the extent of AS, as well as in extrapolating animal studies to humans (Vilahur et al., 2011). The evaluation of AS regression presents a problem especially because the probability of cardiovascular events is stochastic and not only dependent on size of the plaque. Due to this, interpreting clinical studies in a manner of regression can also be difficult.

\section{Autoimmunity and atherogenesis}

Our understanding of AS has been crucially changed from a simply degenerative disorder to one that is a complex, inflammatory and autoimmune disease, in which all branches of immune system are involved. The role of autoimmunity has been shown in clinical and experimental models. Active immunization with HSP-60 or $\beta 2$-GPI induces autoantibodies and accelerates AS. The transfer of lymphocytes from $\beta 2$-GPI-immunized mice to other mice resulted in advanced AS (Sherer \& Shoenfeld, 2006).

The AS process may be magnified and accelerated in patients with autoimmune diseases. Autoimmunity-related risk factors according to Bijl et al. include the presence of anticardiolipid antibodies (aCL), antibodies against oxLDL, antibodies against endothelial cells, antibodies against neutrophil cytoplasm antigens, antibodies against ribonuclear proteins and antibodies against lipoprotein lipase (Bijl, 2003). Additional risk factors recorded by Ronda and Meroni included anti-HSP-60/70 antibodies and anti- $\beta 2$-glycoprotein ( $\beta 2-\mathrm{GPI})$ antibodies (Ronda \& Meroni, 2008). It must be pointed out however, that HSP-70 antigen itself is protective for AS (Frostegard, 2005).

The acceleration of AS in patients with autoimmune disease is due to the underlying immune system dysfunction, the presence of systemic inflammation and endothelial activation with the effects of chronic therapies (Ronda \& Meroni, 2008). Accelerated and premature AS is associated specifically with autoimmune rheumatic diseases of inflammatory nature, most markedly with SLE (Roman et al., 2003; Salmon \& Roman, 2008) and antiphospholipid syndrome (APS) (Jara et al., 2007), but also with RA (Salmon \& Roman, 2008) and SSc (Shoenfeld et al., 2005), certain forms of vasculitis (Shoenfeld et al., 2005) and Sjogren's Syndrome (Gerli et al., 2010; Vaudo et al., 2005). For SSc however, the data are still inconsistent (Zinger et al., 2009).

Many components of the immune system are involved in AS and all arms of the immune system are engaged in atherogenesis with different cells (such as monocytes, macrophages, $\mathrm{T}$ lymphocytes) and different molecules involving both the cellular and humoral, innate and adaptive immunity. Certain important mechanisms for AS in autoimmune diseases are proposed below. One of them postulates that pre-existing adaptive and innate immunity involving HSP-60 exposed on the arterial endothelial cells could lead to the development of an initial inflammatory stage of atherogenesis. The progress of AS depends on the expression and accessibility of atherogenic HSP-60 epitopes on endothelial cells. Since low level of autoimmunity to HSP-60 is evolutionary present in all individuals, the development of AS depends mainly or even exclusively, on the condition of the endothelial cells (Wick \& et al., 2006). 32 -GPI is another autoantigen expressed within subendothelial regions and intimal-medial border of human atherosclerotic plagues, suggested to be involved in atherogenesis. It is targeted by anti- 
$\beta 2-$ GPI antibodies, which results in increased amounts of colocalized CD4+ lymphocytes in the endothelia (Ronda \& Meroni, 2008; Shoenfeld et al., 2001). These antibodies can also induce a pro-inflammatory and procoagulant phenotype (Harats \& George, 2001). $32-\mathrm{GPI}$ can also form complexes with oxLDL, which stimulate the immune system to produce autoantibodies to these oxLDL/ $\beta 2$-GPI complexes. Such immune complexes are uptaken by macrophages. Complexes, together with autoantibodies, have been described in patients with SLE and/or APS, indicating another mechanism of accelerated AS in patients with underlaying autoimmune disease (Matsuura et al., 2009). Further data is emerging that IgG anti-oxLDL/ $\beta 2$-GPI antibodies have been associated with proatherogenic functions, whereas IgM anti-oxLDL/ $\beta 2$-GPI have been considered to be antiatherogenic (Narshi et al., 2011). In our recent study of 70 RA female patients, which were followed for 5.5 years, neither antibodies against $\beta 2-\mathrm{GPI}$, nor rheumatoid factor or CRP contributed to AS progression, as measured by carotid intima media thickness and number of plaques (Holc et al., 2011).

The increased risk of AS in patients with autoimmune rheumatic diseases is explained only in part by traditional AS risk factors, such as those from the Framingham study (Lloyd-Jones et al., 2004; Tegos et al., 2001), for example autoimmune patients commonly have dislipidemias. The process of inflammation (as a nontraditional risk factor) can aggravate atherosclerosis via different mechanisms secondary to autoimmunity and infectious diseases. Increased levels or presence of inflammatory markers: CRP, SAA, fibrinogen, IL-6, cluster differentiation markers CD40/CD40L and adhesion molecules have been reported (Shoenfeld et al., 2005).

Peroxidation of LDLs is low in the blood, but is extensive in the intima. Oxygen radicals and oxidizing enzymes modify proteins and lipids of the LDL, which activate endothelial cells to express vascular cell adhesion molecules (L. Badimon et al., 2011). OxLDL is a target of the immune system resulting in the production of autoantibodies (R. Wu \& Lefvert, 1995), which could be, on one hand, an enhancer of oxLDL uptake by macrophages, inflammation and atherogenesis (Ronda \& Meroni, 2008) or, on the other hand, may contribute to oxLDL clearance in healthy persons (Cerne et al., 2002). Antibodies against HDL have also been implicated in AS. Cross-reactivity is thought to exist between aCL, anti-HDL and antiApoA-I IgG antibodies in patients with SLE and primary APS and can lead to the diminishing HDL's protective role (Delgado Alves et al., 2003; Shoenfeld et al., 2005; Tincani et al., 2006).

A representative compilation of autoimmune diseases with accelerated AS is provided below (Figure 3).

Possible risk factors for AS in autoimmune diseases also represent frequently accompanying renal involvement. Questions were raised if plaques are more prone to rupture due to the fact that they are also qualitatively different in autoimmune diseases. Since systemic autoimmune disease patients are on drug therapy for life, there is a need to stress the influence of some common drugs. For instance, corticosteroids increase triglyceride levels, while methotrexate increases the levels of serum homocysteine (Frostegard, 2005).

Vaccination represents an attractive approach to induce long-term protective immunity. Atherosclerosis was reduced by vaccination with oxLDL or HSP-60 in animal experiments (Hansson, 2005) that could be due to the induction of protective antibodies or T cells. 


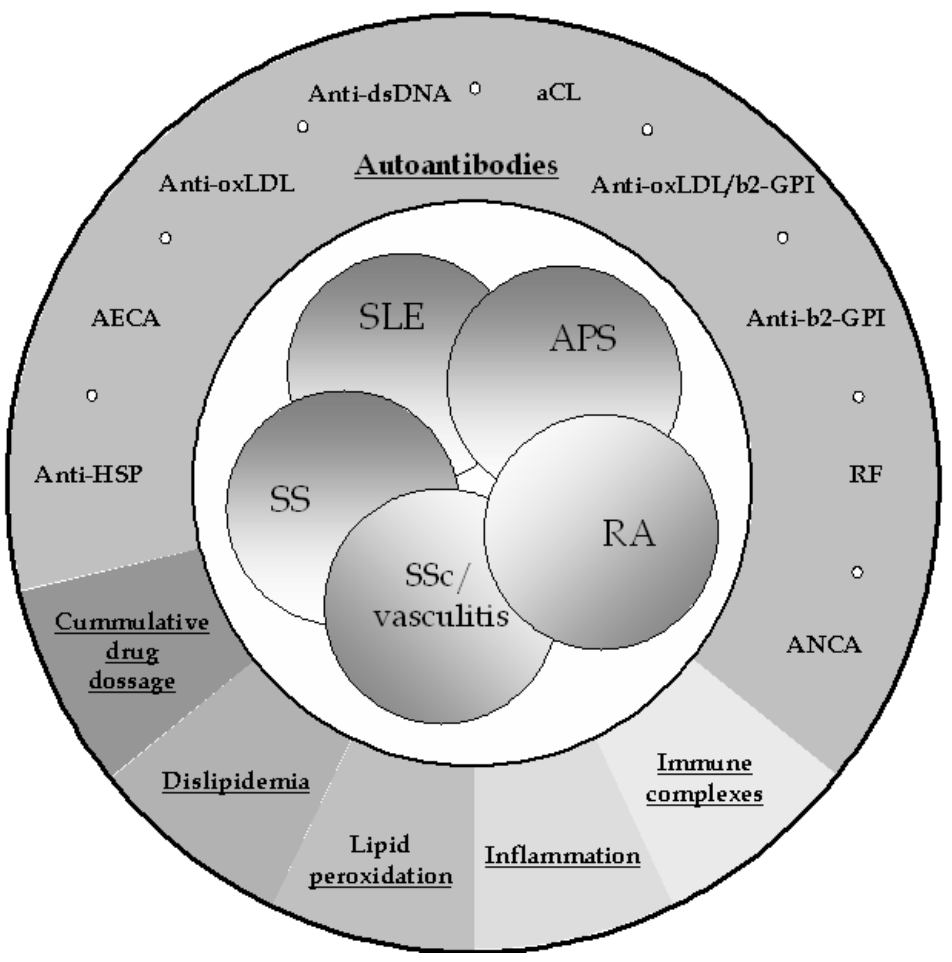

Fig. 3. Representative compilation of autoimmune diseases with accelerated AS with the processes and autoantibodies indicated. aCL, antibodies against cardiolipin; AECA, antiendothelial cell antibodies; ANCA, anti-neutrophil cytoplasmic antibodies; Anti- $\beta 2-G P I$, antibodies against $\beta 2$-glycoprotein I; Anti-dsDNA, antibodies against double stranded DNA; Anti-HSP, antibodies against heat-shock protein antibodies; Anti-oxLDL, antibodies against oxidized LDL; Anti-oxLDL/ $\beta 2-$ GPI, antibodies against oxidized LDL/ $\beta 2-$ glycoprotein I complexes; RF, rheumatoid factor; APS, antiphospholipid syndrome; RA, rheumatoid arthritis; SLE, systemic lupus erythematosus; SS, Sjogren's syndrome; SSc, systemic sclerosis

\section{Antiinflammatory atheroprotective effects and therapies in atherosclerosis}

A growing body of evidence indicates that inflammation not only provides the baseline for future atherosclerotic events, but is a necessity for coronary plaque formation. The unique responsiveness of human coronary artery endothelial cells could account for the greater susceptibility of coronary arteries to inflammation and atherogenesis leading to cardiovascular pathology. Both black tea extract and resveratrol have been shown to significantly inhibit IL-1 $\beta$-induced IL- 6 and tissue factor expression and activity responses in human coronary artery endothelial cells (Lakota et al.., 2009).

The downregulation of TNF-alpha induced by skeletal muscle derived IL-6 may also participate in mediating the atheroprotective effect of physical activity (Szostak \& Laurant, 2011). 
Powerful anti-inflammatory agents could represent treatments for acute coronary syndrome (Hansson, 2005; Libby, 2002; Nilsson et al., 2005). Eicosanoid-modulating anti-inflammatory compounds, such as the cyclooxygenase-2 inhibitor rofecoxib are inappropriate in patients with CVD, since enzymes inhibited by them, are important in both the production of proand anti-thrombotic eicosanoids, depending on the cells effected. Lipid-lowering statins also have anti-inflammatory properties, likely stemming from the ability of statins to inhibit the formation of mevalonic acid, effecting cholesterol, as well as several isoprenoid intermediates used by lipids to attach to different intracellular signaling molecules. In certain studies, the reduction of inflammation (reflected by CRP levels) through statin therapy improved the clinical outcome of CAD, independently of the reduction in serum cholesterol levels (Hansson, 2005).

When macrophages are appropriately activated they can secrete anti-inflammatory cytokines and synthesize matrix repair proteins that stabilize vulnerable plaques (Wilson, 2010). There are also many results from mice studies which show that modulating the activity of selected cytokines (either systemically or locally) can prevent or retard the development of atherosclerotic lesions and could significantly contribute to early detection and treatment of AS or in combination with established hypolipidaemic and antihypertensive treatment. The activity of the cytokines of interest can be modulated by different techniques such as genetic deletion, overexpression, immunoneutralization, or in vivo administration of the cytokines or their receptors or inhibitors (Kleemann et al., 2008).

Chlamydia pneumoniae (Cp) infection has been associated with AS, and beneficial effects of antibiotic therapy on future cardiovascular events have been described. For example, a dramatic reduction in endpoints (cardiovascular death, hospital admission with unstable angina or acute myocardial infarction or need for revascularization) in a small number of high risk patients with CAD suggested the potential of azithromycin therapy in preventing future acute cardiac events (Mehta et al., 1998). The reduced intima media thickness progression after roxithromycin therapy in $\mathrm{Cp}$ seropositivity may be explained by several beneficial effects of antibiotic treatment on atherosclerotic plaque formation, such as those attributable to a reduced smooth muscle cell proliferation or a decreased smooth muscle cell migration from the media and adventitia into the intima, a reduced lipid accumulation, an improvement of endothelial function, and diminished inflammatory activity (Sander et al., 2002). The group reported a significant reduction of CRP in the Cp-positive group of patients with ischemic stroke treated with roxithromycin in a two year follow-up study. In contrast, there was no significant change of CRP in the placebo-treated Cp-positive group. Reductions in CRP and other inflammatory markers were also observed in previous antibiotic trials (Gurfinkel et al., 1999; Muhlestein et al., 2000).

\section{Conclusion}

Taken together, AS is a complex, multi-component, inflammatory, as well as autoimmune disease. Balancing pro- and anti-inflammatory mediators, destructive and protective antibodies can be one approach to maintaining homeostasis. Serum markers of inflammation have emerged as an important component of cardiovascular risk factor burden. On the other hand, some current reports indicate that detection of novel inflammatory marker levels (i.e. using microchips or multi-marker panels) are adding only minimally to the ability of traditional risk factors to predict cardiovascular outcome. However, discovering novel detection methods for different types of markers may be a way 
to help clinicians in identifying/clarifying which patients are at borderline risk and require drug therapy earlier. Fine-tuning the stage of disease progression using appropriate medication can lead to AS regression. Clinicians need more information to support their optimal judgment in this crucial decision-making process. Further directions suggest more predictive and personalized multi-marker medicine and appropriate earlier risk intervention. In addition, more preventive care and participatory feedback are necessary.

\section{References}

Aird, W.C. (2007). Phenotypic heterogeneity of the endothelium: I. Structure, function, and mechanisms. Circ Res, Vol.100, No.2, (February 2007), pp. 158-173, ISSN 1524-4571

Allam, A.H.; Thompson, R.C.; Wann, L.S.; Miyamoto, M.I.; Nur El-Din Ael, H.; El-Maksoud, G.A., et al. (2011). Atherosclerosis in ancient Egyptian mummies: the Horus study. JACC Cardiovasc Imaging, Vol.4, No.4, (April 2011), pp. 315-327, ISSN 1876-7591

Allam, A.H.; Thompson, R.C.; Wann, L.S.; Miyamoto, M.I. \& Thomas, G.S. (2009). Computed tomographic assessment of atherosclerosis in ancient Egyptian mummies. JAMA, Vol.302, No.19, (November 2009), pp. 2091-2094, ISSN 1538-3598

Altman, R. (2003). Risk factors in coronary atherosclerosis athero-inflammation: the meeting point. Thromb J, Vol.1, No.1, (July 2003), pp. 4, ISSN 1477-9560

Ayada, K.; Yokota, K.; Kobayashi, K.; Shoenfeld, Y.; Matsuura, E. \& Oguma, K. (2007). Chronic infections and atherosclerosis. Ann N Y Acad Sci, Vol.1108, (June 2007), pp. 594-602, ISSN 0077-8923

Badimon, J.J.; Badimon, L. \& Fuster, V. (1990). Regression of atherosclerotic lesions by high density lipoprotein plasma fraction in the cholesterol-fed rabbit. J Clin Invest, Vol.85, No.4, (April 1990), pp. 1234-1241, ISSN 0021-9738

Badimon, L.; Storey, R.F. \& Vilahur, G. (2011). Update on lipids, inflammation and atherothrombosis. Thromb Haemost, Vol.105 Suppl 1, (May 2011), pp. S34-42, ISSN 0340-6245

Bai, X.; Wang, X. \& Xu, Q. (2010). Endothelial damage and stem cell repair in atherosclerosis. Vascul Pharmacol, Vol.52, No.5-6, (May-Jun 2010), pp. 224-229, ISSN 1879-3649

Beers, M.H.; Porter, S.R.; Jones, V.T.; Kaplan, L.J. \& Berkwits, M., Eds. (2006). The Merck manual of diagnosis and therapy, Merck Research Laboratories, Division of Merck \& Co., INC., ISBN 0-911910-18-2, Whitehouse Station, NJ

Bijl, M. (2003). Endothelial activation, endothelial dysfunction and premature atherosclerosis in systemic autoimmune diseases. Neth J Med, Vol.61, No.9, (September 2003), pp. 273-277, ISSN 0300-2977

Boon, B. (2009). Leonardo da Vinci on atherosclerosis and the function of the sinuses of Valsalva. Neth Heart J, Vol.17, No.12, (December 2009), pp. 496-499, ISSN 1876-6250

Boos, C.J.; Lip, G.Y. \& Blann, A.D. (2006). Circulating endothelial cells in cardiovascular disease. J Am Coll Cardiol, Vol.48, No.8, (October 2006), pp. 1538-1547, ISSN 15583597

Cerne, D.; Jurgens, G.; Ledinski, G.; Kager, G.; Greilberger, J. \& Lukac-Bajalo, J. (2002). Relationship between the sialic acid content of low-density lipoprotein (LDL) and autoantibodies to oxidized LDL in the plasma of healthy subjects and patients with atherosclerosis. Clin Chem Lab Med, Vol.40, No.1, (January 2002), pp. 15-20, ISSN 1434-6621

Chait, A.; Han, C.Y.; Oram, J.F. \& Heinecke, J.W. (2005). Thematic review series: The immune system and atherogenesis. Lipoprotein-associated inflammatory proteins: 
markers or mediators of cardiovascular disease? J Lipid Res, Vol.46, No.3, (March 2005), pp. 389-403, ISSN 0022-2275

Cines, D.B.; Pollak, E.S.; Buck, C.A.; Loscalzo, J.; Zimmerman, G.A.; McEver, R.P., et al. (1998). Endothelial cells in physiology and in the pathophysiology of vascular disorders. Blood, Vol.91, No.10, (May 1998), pp. 3527-3561, ISSN 0006-4971

Colley, K.J.; Wolfert, R.L. \& Cobble, M.E. (2011). Lipoprotein associated phospholipase A(2): role in atherosclerosis and utility as a biomarker for cardiovascular risk. EPMA $J$, Vol.2, No.1, (March 2011), pp. 27-38, ISSN 1878-5085

Delgado Alves, J.; Kumar, S. \& Isenberg, D.A. (2003). Cross-reactivity between anticardiolipin, anti-high-density lipoprotein and anti-apolipoprotein A-I IgG antibodies in patients with systemic lupus erythematosus and primary antiphospholipid syndrome. Rheumatology (Oxford), Vol.42, No.7, (July 2003), pp. 893-899, ISSN 1462-0324

Deng, D.X.; Tsalenko, A.; Vailaya, A.; Ben-Dor, A.; Kundu, R.; Estay, I., et al. (2006). Differences in vascular bed disease susceptibility reflect differences in gene expression response to atherogenic stimuli. Circ Res, Vol.98, No.2, (February 2006), pp. 200-208, ISSN 1524-4571

Duran, A.C.; Rodriguez, C.; Gil de Sola, L.; Fernandez, B.; Arque, J.M. \& Sans-Coma, V. (2010). Intimal thickening of coronary arteries in the rabbitfish, Chimaera monstrosa L. (Chondrichthyes: Holocephali). J Fish Dis, Vol.33, No.8, (August 2010), pp. 675-682, ISSN 1365-2761

Farrell, A.P. (2002). Cardiorespiratory performance in salmonids during exercise at high temperature: insights into cardiovascular design limitations in fishes. Comp Biochem Physiol A Mol Integr Physiol, Vol.132, No.4, (August 2002), pp. 797-810, ISSN 10956433

Frostegard, J. (2005). Atherosclerosis in patients with autoimmune disorders. Arterioscler Thromb Vasc Biol, Vol.25, No.9, (September 2005), pp. 1776-1785, ISSN 1524-4636

Fruchart, J.C.; Nierman, M.C.; Stroes, E.S.; Kastelein, J.J. \& Duriez, P. (2004). New risk factors for atherosclerosis and patient risk assessment. Circulation, Vol.109, No.23 Suppl 1, (June 2004), pp. III15-19, ISSN 1524-4539

Gabrielli, M.; Santarelli, L. \& Gasbarrini, A. (2002). Role for chronic infections in atherosclerosis? Circulation, Vol.106, No.7, (August 2002), pp. e32; author reply 32, ISSN 1524-4539

Gerli, R.; Vaudo, G.; Bocci, E.B.; Schillaci, G.; Alunno, A.; Luccioli, F., et al. (2010). Functional impairment of the arterial wall in primary Sjogren's syndrome: combined action of immunologic and inflammatory factors. Arthritis Care Res (Hoboken), Vol.62, No.5, (May 2010), pp. 712-718, ISSN 2151-4658

Graham, I.; Atar, D.; Borch-Johnsen, K.; Boysen, G.; Burell, G.; Cifkova, R., et al. (2007). European guidelines on cardiovascular disease prevention in clinical practice: executive summary: Fourth Joint Task Force of the European Society of Cardiology and Other Societies on Cardiovascular Disease Prevention in Clinical Practice (Constituted by representatives of nine societies and by invited experts). Eur Heart J, Vol.28, No.19, (October 2007), pp. 2375-2414, ISSN 0195-668X

Gurfinkel, E.; Bozovich, G.; Beck, E.; Testa, E.; Livellara, B. \& Mautner, B. (1999). Treatment with the antibiotic roxithromycin in patients with acute non-Q-wave coronary syndromes. The final report of the ROXIS Study. Eur Heart J, Vol.20, No.2, (January 1999), pp. 121-127, ISSN 0195-668X

Gziut, A.I. \& Gil, R.J. (2008). Coronary aneurysms. Pol Arch Med Wewn, Vol.118, No.12, (December 2008), pp. 741-746, ISSN 0032-3772 
Hansson, G.K. (2005). Inflammation, atherosclerosis, and coronary artery disease. $N$ Engl J Med, Vol.352, No.16, (April 2005), pp. 1685-1695, ISSN 1533-4406

Harats, D. \& George, J. (2001). Beta2-glycoprotein I and atherosclerosis. Curr Opin Lipidol, Vol.12, No.5, (October 2001), pp. 543-546, ISSN 0957-9672

Heistad, D.D.; Armstrong, M.L. \& Lopez, J.A. (1990). What causes spasm of atherosclerotic arteries? Is regression of plaques beneficial? Trans Am Clin Climatol Assoc, Vol.101, 1990), pp. 103-110; discussion 110-113, ISSN 0065-7778

Herder, C.; Baumert, J.; Zierer, A.; Roden, M.; Meisinger, C.; Karakas, M., et al. (2011). Immunological and Cardiometabolic Risk Factors in the Prediction of Type 2 Diabetes and Coronary Events: MONICA/KORA Augsburg Case-Cohort Study. PLoS One, Vol.6, No.6, (June [online] 2011), pp. e19852, ISSN 1932-6203

Herder, C.; Karakas, M. \& Koenig, W. (2011). Biomarkers for the prediction of type 2 diabetes and cardiovascular disease. Clin Pharmacol Ther, Vol.90, No.1, (July 2011), pp. 52-66, ISSN 1532-6535

Holc, I.; Hojs, R.; Cikes, N.; Ambrozic, A.; Cucnik, S.; Kveder, T., et al. (2011). Antiphospholipid antibodies and atherosclerosis: Insights from Rheumatoid arthritis - a five-year follow-up study. Rheumatology (Oxford), ([no date] 2011), pp. [article in press],

Hua, S.; Song, C.; Geczy, C.L.; Freedman, S.B. \& Witting, P.K. (2009). A role for acute-phase serum amyloid A and high-density lipoprotein in oxidative stress, endothelial dysfunction and atherosclerosis. Redox Rep, Vol.14, No.5, (October 2009), pp. 187196, ISSN 1743-2928

Jan, M.; Meng, S.; Chen, N.C.; Mai, J.; Wang, H. \& Yang, X.F. (2010). Inflammatory and autoimmune reactions in atherosclerosis and vaccine design informatics. J Biomed Biotechnol, Vol.2010, (n.d. 2010), pp. ID 459798, ISSN 1110-7251

Jara, L.J.; Medina, G. \& Vera-Lastra, O. (2007). Systemic antiphospholipid syndrome and atherosclerosis. Clin Rev Allergy Immunol, Vol.32, No.2, (April 2007), pp. 172-177, ISSN 1080-0549

Khovidhunkit, W.; Memon, R.A.; Feingold, K.R. \& Grunfeld, C. (2000). Infection and inflammation-induced proatherogenic changes of lipoproteins. J Infect Dis, Vol.181 Suppl 3, (June 2000), pp. S462-472, ISSN 0022-1899

King, V.L.; Thompson, J. \& Tannock, L.R. (2011). Serum amyloid A in atherosclerosis. Curr Opin Lipidol, Vol.22, No.4, (Aug 2011), pp. 302-307, ISSN 1473-6535

Kleemann, R.; Zadelaar, S. \& Kooistra, T. (2008). Cytokines and atherosclerosis: a comprehensive review of studies in mice. Cardiovasc Res, Vol.79, No.3, (August 2008), pp. 360-376, ISSN 0008-6363

Kowalski, M.; Pawlik, M.; Konturek, J.W. \& Konturek, S.J. (2006). Helicobacter pylori infection in coronary artery disease. J Physiol Pharmacol, Vol.57 Suppl 3, (September 2006), pp. 101-111, ISSN 1899-1505

Krone, W. \& Muller-Wieland, D. (1999). Lipid lowering therapy and stabilization of atherosclerotic plaques. Thromb Haemost, Vol.82 Suppl 1, (September 1999), pp. 6061, ISSN 0340-6245

Kullo, I.J. \& Ballantyne, C.M. (2005). Conditional risk factors for atherosclerosis. Mayo Clin Proc, Vol.80, No.2, (February 2005), pp. 219-230, ISSN 0025-6196

Kumar, V.; Abbas, A.K.; Fausto, N. \& Mitchell, R.N., Eds. (2007). Robbins Basic Pathology Saunders/Elsevier, ISBN 978-1-4160-2973-1, Philadelphia

Lacorre, D.A.; Baekkevold, E.S.; Garrido, I.; Brandtzaeg, P.; Haraldsen, G.; Amalric, F., et al. (2004). Plasticity of endothelial cells: rapid dedifferentiation of freshly isolated high 
endothelial venule endothelial cells outside the lymphoid tissue microenvironment. Blood, Vol.103, No.11, (June 2004), pp. 4164-4172, ISSN 0006-4971

Lakota, K.; Mrak-Poljsak, K.; Rozman, B.; Kveder, T.; Tomsic, M. \& Sodin-Semrl, S. (2007). Serum amyloid A activation of inflammatory and adhesion molecules in human coronary artery and umibilical vein endothelial cells. European Journal of Inflammation, Vol.5, No.2,(2007), pp. 73-81, ISSN 1721-727X

Lakota, K.; Mrak-Poljsak, K.; Rozman, B. \& Sodin-Semrl, S. (2009). Increased responsiveness of human coronary artery endothelial cells in inflammation and coagulation. Mediators Inflamm, Vol.2009, (2009), pp. 146872, ISSN 1466-1861

Lehle, K.; Kunz-Schughart, L.A.; Kuhn, P.; Schreml, S.; Birnbaum, D.E. \& Preuner, J.G. (2007). Validity of a patient-derived system of tissue-specific human endothelial cells: interleukin-6 as a surrogate marker in the coronary system. Am J Physiol Heart Circ Physiol, Vol.293, No.3, (September 2007), pp. H1721-1728, ISSN 0363-6135

Libby, P. (2002). Inflammation in atherosclerosis. Nature, Vol.420, No.6917, (December 2002), pp. 868-874, ISSN 0028-0836

Libby, P.; Ridker, P.M. \& Hansson, G.K. (2011). Progress and challenges in translating the biology of atherosclerosis. Nature, Vol.473, No.7347, (May 2011), pp. 317-325, ISSN 1476-4687

Lloyd-Jones, D.M.; Wilson, P.W.; Larson, M.G.; Beiser, A.; Leip, E.P.; D'Agostino, R.B., et al. (2004). Framingham risk score and prediction of lifetime risk for coronary heart disease. Am J Cardiol, Vol.94, No.1, (July 2004), pp. 20-24, ISSN 0002-9149

Ludewig, B.; Krebs, P. \& Scandella, E. (2004). Immunopathogenesis of atherosclerosis. J Leukoc Biol, Vol.76, No.2, (August 2004), pp. 300-306, ISSN 0741-5400

Luu, N.T.; Rahman, M.; Stone, P.C.; Rainger, G.E. \& Nash, G.B. (2010). Responses of endothelial cells from different vessels to inflammatory cytokines and shear stress: evidence for the pliability of endothelial phenotype. J Vasc Res, Vol.47, No.5, (August 2010), pp. 451-461, ISSN 1423-0135

Malinow, M.R. (1983). Experimental models of atherosclerosis regression. Atherosclerosis, Vol.48, No.2, (August 1983), pp. 105-118, ISSN 0021-9150

Malle, E. \& De Beer, F.C. (1996). Human serum amyloid A (SAA) protein: a prominent acute-phase reactant for clinical practice. Eur J Clin Invest, Vol.26, No.6, (June 1996), pp. 427-435, ISSN 0014-2972

Matsuura, E.; Kobayashi, K. \& Lopez, L.R. (2009). Atherosclerosis in autoimmune diseases. Curr Rheumatol Rep, Vol.11, No.1, (February 2009), pp. 61-69, ISSN 1534-6307

Mayranpaa, M.I.; Heikkila, H.M.; Lindstedt, K.A.; Walls, A.F. \& Kovanen, P.T. (2006). Desquamation of human coronary artery endothelium by human mast cell proteases: implications for plaque erosion. Coron Artery Dis, Vol.17, No.7, (November 2006), pp. 611-621, ISSN 0954-6928

Mehta, J.L.; Saldeen, T.G. \& Rand, K. (1998). Interactive role of infection, inflammation and traditional risk factors in atherosclerosis and coronary artery disease. J Am Coll Cardiol, Vol.31, No.6, (May 1998), pp. 1217-1225, ISSN 0735-1097

Methe, H.; Balcells, M.; Alegret Mdel, C.; Santacana, M.; Molins, B.; Hamik, A., et al. (2007). Vascular bed origin dictates flow pattern regulation of endothelial adhesion molecule expression. Am J Physiol Heart Circ Physiol, Vol.292, No.5, (May 2007), pp. H2167-2175, ISSN 0363-6135

Moubayed, S.P.; Heinonen, T.M. \& Tardif, J.C. (2007). Anti-inflammatory drugs and atherosclerosis. Curr Opin Lipidol, Vol.18, No.6, (December 2007), pp. 638-644, ISSN 0957-9672 
Muhlestein, J.B.; Anderson, J.L.; Carlquist, J.F.; Salunkhe, K.; Horne, B.D.; Pearson, R.R., et al. (2000). Randomized secondary prevention trial of azithromycin in patients with coronary artery disease: primary clinical results of the ACADEMIC study. Circulation, Vol.102, No.15, (October 10 2000), pp. 1755-1760, ISSN 1524-4539

Mutin, M.; Canavy, I.; Blann, A.; Bory, M.; Sampol, J. \& Dignat-George, F. (1999). Direct evidence of endothelial injury in acute myocardial infarction and unstable angina by demonstration of circulating endothelial cells. Blood, Vol.93, No.9, (May 1999), pp. 2951-2958, ISSN 0006-4971

Narshi, C.B.; Giles, I.P. \& Rahman, A. (2011). The endothelium: an interface between autoimmunity and atherosclerosis in systemic lupus erythematosus? Lupus, Vol.20, No.1, (January 2011), pp. 5-13, ISSN 1477-0962

Nilsson, J.; Hansson, G.K. \& Shah, P.K. (2005). Immunomodulation of atherosclerosis: implications for vaccine development. Arterioscler Thromb Vasc Biol, Vol.25, No.1, (January 2005), pp. 18-28, ISSN 1524-4636

Ott, S.J.; El Mokhtari, N.E.; Musfeldt, M.; Hellmig, S.; Freitag, S.; Rehman, A., et al. (2006). Detection of diverse bacterial signatures in atherosclerotic lesions of patients with coronary heart disease. Circulation, Vol.113, No.7, (February 2006), pp. 929-937, ISSN 1524-4539

Roger, V.L.; Go, A.S.; Lloyd-Jones, D.M.; Adams, R.J.; Berry, J.D.; Brown, T.M., et al. (2011). Heart disease and stroke statistics--2011 update: a report from the American Heart Association. Circulation, Vol.123, No.4, (February 2009 2011), pp. e18-e209, ISSN 1524-4539

Roman, M.J.; Shanker, B.A.; Davis, A.; Lockshin, M.D.; Sammaritano, L.; Simantov, R., et al. (2003). Prevalence and correlates of accelerated atherosclerosis in systemic lupus erythematosus. N Engl J Med, Vol.349, No.25, (December 2003), pp. 2399-2406, ISSN $1533-4406$

Ronda, N. \& Meroni, P.L. (2008). Accelerated Atherosclerosis in Autoimmune diseases, In. Diagnostic Criteria in Autoimmune Diseases, Shoenfeld, Y.; Cervera, R.\& Gershwin, M. E., 383-388, Humana Press, ISBN 978-1-60327-284-1, Totowa

Ross, R. (1999). Atherosclerosis--an inflammatory disease. N Engl J Med, Vol.340, No.2, (January 1999), pp. 115-126, ISSN 0028-4793

Salmon, J.E. \& Roman, M.J. (2008). Subclinical atherosclerosis in rheumatoid arthritis and systemic lupus erythematosus. Am J Med, Vol.121, No.10 Suppl 1, (October 2008), pp. S3-8, ISSN 1555-7162

Sander, D.; Winbeck, K.; Klingelhofer, J.; Etgen, T. \& Conrad, B. (2002). Reduced progression of early carotid atherosclerosis after antibiotic treatment and Chlamydia pneumoniae seropositivity. Circulation, Vol.106, No.19, (November 5 2002), pp. 2428-2433, ISSN 1524-4539

Sherer, Y. \& Shoenfeld, Y. (2006). Mechanisms of disease: atherosclerosis in autoimmune diseases. Nat Clin Pract Rheumatol, Vol.2, No.2, (February 2006), pp. 99-106, ISSN $1745-8382$

Shoenfeld, Y.; Gerli, R.; Doria, A.; Matsuura, E.; Cerinic, M.M.; Ronda, N., et al. (2005). Accelerated atherosclerosis in autoimmune rheumatic diseases. Circulation, Vol.112, No.21, (November 2005), pp. 3337-3347, ISSN 1524-4539

Shoenfeld, Y.; Sherer, Y. \& Harats, D. (2001). Artherosclerosis as an infectious, inflammatory and autoimmune disease. Trends Immunol, Vol.22, No.6, (June 2001), pp. 293-295, ISSN 1471-4906 
Stoltz, J.F.; Muller, S.; Kadi, A.; Decot, V.; Menu, P. \& Bensoussan, D. (2007). Introduction to endothelial cell biology. Clin Hemorheol Microcirc, Vol.37, No.1-2, (June 2007), pp. 58, ISSN 1386-0291

Szostak, J. \& Laurant, P. (2011). The forgotten face of regular physical exercise: a 'natural' anti-atherogenic activity. Clin Sci (Lond), Vol.121, No.3, (August 2011), pp. 91-106, ISSN 1470-8736

Tegos, T.J.; Kalodiki, E.; Sabetai, M.M. \& Nicolaides, A.N. (2001). The genesis of atherosclerosis and risk factors: a review. Angiology, Vol.52, No.2, (February 2001), pp. 89-98, ISSN 0003-3197

Tincani, A.; Rebaioli, C.B.; Taglietti, M. \& Shoenfeld, Y. (2006). Heart involvement in systemic lupus erythematosus, anti-phospholipid syndrome and neonatal lupus. Rheumatology (Oxford), Vol.45 Suppl 4, (October 2006), pp. iv8-13, ISSN 1462-0332

Vallejo, J.G. (2011). Role of toll-like receptors in cardiovascular diseases. Clin Sci (Lond), Vol.121, No.1, (July 2011), pp. 1-10, ISSN 1470-8736

Vaudo, G.; Bocci, E.B.; Shoenfeld, Y.; Schillaci, G.; Wu, R.; Del Papa, N., et al. (2005). Precocious intima-media thickening in patients with primary Sjogren's syndrome. Arthritis Rheum, Vol.52, No.12, (December 2005), pp. 3890-3897, ISSN 0004-3591

Viemann, D.; Goebeler, M.; Schmid, S.; Nordhues, U.; Klimmek, K.; Sorg, C., et al. (2006). TNF induces distinct gene expression programs in microvascular and macrovascular human endothelial cells. J Leukoc Biol, Vol.80, No.1, (July 2006), pp. 174-185, ISSN 0741-5400

Vilahur, G.; Padro, T. \& Badimon, L. (2011). Atherosclerosis and thrombosis: insights from large animal models. J Biomed Biotechnol, Vol.2011, (n.d. 2011), pp. ID 907575, ISSN $1110-7251$

Wick, G. \& et al. (2006). Atherosclerosis: autoimmunity to heat-shock proteins, In. The autoimmune diseases, Rose, N. R.\& Mackay, I. R., 889-897, Academic Press, ISBN-13 978-0-12-595961-2, San Diego

Williams, K.J.; Feig, J.E. \& Fisher, E.A. (2008). Rapid regression of atherosclerosis: insights from the clinical and experimental literature. Nat Clin Pract Cardiovasc Med, Vol.5, No.2, (February 2008), pp. 91-102, ISSN 1743-4300

Wilson, H.M. (2010). Macrophages heterogeneity in atherosclerosis - implications for therapy. J Cell Mol Med, Vol.14, No.8, (August 2010), pp. 2055-2065, ISSN 1582-4934

$\mathrm{Wu}$, J.T. \& Wu, L.L. (2005). Association of soluble markers with various stages and major events of atherosclerosis. Ann Clin Lab Sci, Vol.35, No.3, (Summer 2005), pp. 240250, ISSN 0091-7370

Wu, R. \& Lefvert, A.K. (1995). Autoantibodies against oxidized low density lipoproteins (oxLDL): characterization of antibody isotype, subclass, affinity and effect on the macrophage uptake of oxLDL. Clin Exp Immunol, Vol.102, No.1, (October 1995), pp. 174-180, ISSN 0009-9104

Yano, K.; Gale, D.; Massberg, S.; Cheruvu, P.K.; Monahan-Earley, R.; Morgan, E.S., et al. (2007). Phenotypic heterogeneity is an evolutionarily conserved feature of the endothelium. Blood, Vol.109, No.2, (January 2007), pp. 613-615, ISSN 0006-4971

Zimmerman, M.R. (1998). Aleutian and Alaskan mummies, In. Mummies, Disease and Ancient Cultures, Cockburn, A.; Cockburn, E.\& Reyman, T. A., 138-141, University Press, ISBN-13 9780521589543, Cambridge

Zinger, H.; Sherer, Y. \& Shoenfeld, Y. (2009). Atherosclerosis in autoimmune rheumatic diseases-mechanisms and clinical findings. Clin Rev Allergy Immunol, Vol.37, No.1, (August 2009), pp. 20-28, ISSN 1559-0267 


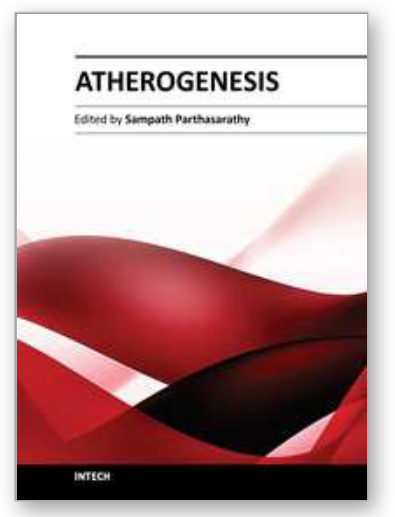

\author{
Atherogenesis \\ Edited by Prof. Sampath Parthasarathy
}

ISBN 978-953-307-992-9

Hard cover, 570 pages

Publisher InTech

Published online 11, January, 2012

Published in print edition January, 2012

This monograph will bring out the state-of-the-art advances in the dynamics of cholesterol transport and will address several important issues that pertain to oxidative stress and inflammation. The book is divided into three major sections. The book will offer insights into the roles of specific cytokines, inflammation, and oxidative stress in atherosclerosis and is intended for new researchers who are curious about atherosclerosis as well as for established senior researchers and clinicians who would be interested in novel findings that may link various aspects of the disease.

\title{
How to reference
}

In order to correctly reference this scholarly work, feel free to copy and paste the following:

Katja Lakota, Andrej Artenjak, Sasa Cucnik, Jana Brguljan-Hitij, Borut Cegovnik, Barbara Salobir, Rok Accetto, Borut Bozic, Blaz Rozman and Snezna Sodin-Semrl (2012). Atherogenesis, Inflammation and Autoimmunity An Overview, Atherogenesis, Prof. Sampath Parthasarathy (Ed.), ISBN: 978-953-307-992-9, InTech, Available from: http://www.intechopen.com/books/atherogenesis/atherogenesis-inflammation-and-autoimmunity-anoverview

\section{INTECH}

open science | open minds

\section{InTech Europe}

University Campus STeP Ri Slavka Krautzeka 83/A 51000 Rijeka, Croatia Phone: +385 (51) 770447

Fax: +385 (51) 686166 www.intechopen.com

\section{InTech China}

Unit 405, Office Block, Hotel Equatorial Shanghai No.65, Yan An Road (West), Shanghai, 200040, China 中国上海市延安西路65号上海国际贵都大饭店办公楼405单元 Phone: +86-21-62489820

Fax: $+86-21-62489821$ 
(C) 2012 The Author(s). Licensee IntechOpen. This is an open access article distributed under the terms of the Creative Commons Attribution 3.0 License, which permits unrestricted use, distribution, and reproduction in any medium, provided the original work is properly cited. 